\title{
THE MIND-BODY PROBLEM FROM AN EMERGENTIST APPROACH: A DEFENSE OF A PHYSICALISM BASED ON THE LEVELS OF COMPLEXITY OF THE NATURE AND ON THE IRREDUCIBILITY OF EMERGENT PROPERTIES*
}

\author{
Leonardo Ferreira Almada \\ Universidade Federal de Uberlândia
}

\begin{abstract}
This paper is part of the research project I am developing, and whose purpose is to build a theoretical model dedicated to classic and always reinvented 'problem of mind-body relationships'. The present stage of this research is devoted to reconcile an emergentist perspective of mental properties with the thesis that the mind emerges from the interaction and integration relationships between encephalon, body proper, and environment. To this end, I will seek to demarcate the reasons to support an approach which is monistic and, at the same time, incompatible with the physicalist perspectives that have adhered to a greater or lesser degree to the reductionist program. Throughout my research, I want to argue that the emergentist perspective is the one that best meets these demands. Contrary to the reductionistic physicalism, I propose to defend a physicalism centered on the notions of complexity and irreducibility of the emergent properties.
\end{abstract}

Keywords: Emergentism, physicalism, layered view of reality, complexity, irreducibility.

Resumo: O presente paper integra o projeto de pesquisa que estou desenvolvendo, e cuja finalidade é a de erigir um modelo teórico dedicado ao clássico e sempre reinventado 'problema das relações mentecorpo'. O estágio atual desta pesquisa se dedica a conciliar uma perspectiva emergentista das propriedades mentais com a tese de que a mente emerge das indissociáveis relações de interação e de integração entre encéfalo, corpo-propriamente-dito e meio-ambiente. Para tanto, buscarei demarcar as razões para defender uma abordagem que seja monista e, ao mesmo tempo, incompatível com as perspectivas fisicalistas que aderiram em maior ou menor grau ao programa reducionista. Como pretendo sustentar, a perspectiva emergentista é a que melhor se adequa a essas exigências. Em sentido diverso do fisicalismo reducionista, proponho a defesa de um fisicalismo centrado nas noções de complexidade e de irredutibilidade das propriedades emergentes.

Palavras-chave: Emergentismo, fisicalismo, visão estratificada da realidade, complexidade, irredutibilidade.

\footnotetext{
* Firstly, I want to thank with sincerity and gratefulness the valuable comments and suggestions of Prof. Dr. André Porto (FAFIL-UFG / PPGFIL-UFG). I also wish to publish my thanks to Prof. Dr. Eros Moreira Carvalho (DEFIL-UFRGS / PPGFIL-UFRGS), who, through a brief question, encouraged me to advance my research on the emergence of complexity. I also want to thank Marcelo Fischborn (UFSM) for an important question addressed to me at a conference/workshop on naturalism and cognitive sciences. Thank you to the reviewers for the reading and evaluating this work. I am especially grateful to my Espatódea, whose daily love, inspiration and assistance contributed to the achievement of this work.
} 


\section{Introduction}

\subsection{Contextualization of the Paper}

Throughout the present paper, I will attempt to introduce the general lines of one of the early stages of the research I am currently developing in Philosophy of Mind. The research with which I am currently engaged was conceived from my aspiration to build a theoretical model devoted to the 'problem of the mind-body relations', one of the most classic and recurring problem in the history of the philosophy. Such a goal was designed to be conducted over two large and independent parts. Although these two parts are independent of each other, they are deeply interrelated. Each one contains a set of productions whose final number is still unpredictable.

In the course of the two parts of my research, I shall deal with the different variables of the theoretical model that I intend to build. Through the development of the components of my theoretical model, I will propose to conceive that the emergence of mental properties is one of the most important results of the interaction and integration relationship between the encephalon or whole brain (cerebrum, cerebellum and brain stem or simply brainstem), the body proper (ie, the body conceived without the brain structure, by means of a consideration of reason) and the environment ${ }^{1}$.

By introducing these variables to the classic solution to the problem, the scope of my research program acquires greater breadth and opens up new investigation possibilities. The theoretical enlargement that I seek to carry forward concerns to the classic way of solving the mind-body relationship. Through the aforementioned expansion of my research scope, I address my concerns to the extended 'space' in which brain, body, and environment relationships are instantiated. The establishment of a theoretical model for what I call the 'problem of consciousness-mind-brain-body-environment relationships' requires a detailed investigation of the 'space' which enables the instantiation of these relations. I think it is clear to all scientifically knowledgeable philosopher that the aforementioned 'space' is precisely found in the boundaries of the physical and of the regulatory laws of the natural world: then it is clear that the establishment of my theoretical model requires further studies on the structure of matter and on the compositional organization of the natural world. In fact, the 'place' of the consciousness in the world is the same one occupied by any other natural phenomenon. So it is true that the emergence of my model requires an answer to the following

1 The division that I establish between these variables go against what is proposed by my model, and therefore is only meant to didactic purposes. 
question: under what conditions do the (conscious) mental beings instantiate mental processes (conscious)? This question addresses the concerns that are at stake in the current moment of my reflection: What enables some (and specific) systems to instantiate (conscious) mental processes? What is the role played by the dynamic relationship between encephalic structure and body in the emergence of mental properties? How the en(active) insertion of the body in the environment takes part in the establishment of mental phenomena or properties? How the body shapes and is shaped for the environment, and what is the role of this relationship in the emergence of mental properties? How can we unravel the group of brain, body and environment relationships that contribute to the establishment of the (conscious) mind? Shall we one day be able to outline the guidelines that would enable us to a standardize a way of equating mental phenomena?

If — as I believe - my theoretical model depends on theoretical positions for the above issues, then it is true that my philosophical endeavor requires different levels of contribution: in other words, my research must be based on an interdisciplinary approach. Indeed, there are many fields of knowledge that can subsidize basic and advanced perspectives and discussions in philosophy of mind: from mathematics to the neurosciences in general. The most diverse 'sciences of the mind', the philosophy of matter, the philosophy of science, philosophy of physics, in addition to the basic physics - especially the standard model of particle physics — contribute greatly to the purposes of my research.

Interdisciplinarity is undoubtedly the most prominent feature of the first part of my research. Indeed, one of my major philosophical aspirations consists in investigating the 'place' of the (conscious) mind in the natural world, or even the 'space' in which brain, body and environment relationships occur. In this sense, the achieving of my goals significantly depends on an appeal to the physics branches devoted to: (i) the investigation of the basic elements of matter, (ii) the discussion about the existence of the most basic and fundamental level of reality, and, finally, (iii) the reflection on the compositional structure of nature. After all, it is within the natural world and within its regulatory laws that organisms endowed with sufficiently complex nervous systems become capable of giving rise to emergent (conscious) mental properties/phenomena/states.

Interdisciplinarity is, therefore, the central mark of the first part of my project. In the first part of my research, my purpose is to outline the structural, methodological, theoretical and conceptual foundations of the theoretical model that I intend to build in the second part of my project. Indeed, I believe that physics (especially particle physics) is the most effective 
theoretical ground to ensure the unity, consistency and cohesion necessary for the further establishment of my model. My aspiration is that the demarcation of my research foundations in the light of what the best available theories of physics teach us, and that this effort can provide the necessary tools to support the project which I have appointed for the second part of my research, namely: the establishment of an emergentist theoretical model, dedicated to the research of the philosophical implications raised by the emergence of mental properties/phenomena from brain, body and environment interaction and integration relationships.

In the previous paper - the first of this series — I began to go through the group of positions which I will defend with respect to the 'space' in which mind, body and environment relationships take place. The goal of this first paper was to outline what we know of the structure of matter and the physical constitution of the world in the light of the best available theories of physics, especially Standard Model of particle physics and others that arose after the decline of mechanism in modern physics.

The general purpose of the present paper and of the next papers of the first part of my project is equivalent to the main goal of my first paper: to highlight the reasons to defend an approach which, although it is monistic, is also, and at the same time, incompatible with some of the main physicalists assumptions, since contemporary physicalisms - both its reductive and nonreductive versions - are encouraged by the reductionist program ${ }^{2}$.

My present purpose is to carry on the discussion - which I began in my previous paper - (i) on the structure of matter and (ii) on the hierarchical levels of complexity of the natural world. My previous study provided me important tools to carry out a comprehensive list on the set of elementary particles of the world, as well as their laws, their forms of interactions, their charges, in addition to the forces and fundamental fields from nature. This research has also provided me the tools to reject the idea according to which the natural world is additively composed, and that this supposed additive composition comes from the fundamental 'pieces' or blocks of matter. More than that, my previous research has provided me tools to reject both a materialist perspective and a philosophical view focused on particles, that is, on a corpuscular paradigm. Furthermore, my previous study also enabled me to support a systemic-materialist worldview, within an emergentist orientation,

2 I believe that the reformist aspirations of non-reductive physicalism is not always accompanied by an effective reformulation of the structural methodological, theoretical and conceptual basis on which are grounded at the same time the classical dualisms and the contemporary reductive physicalists. This understanding is shared by Crane (2001b, 2011), Vintiadis (2013), and, among many others, Gillett (2010). 
focused both on the notions of forces/force fields and on the view that the levels of complexity of the nature do not result from the addition/incorporation of material ingredients. If the relationships of greater or lesser complexity between the different levels cannot be explained by the presence or absence of material ingredients, one of the problems which I will need to deal with is the following: what accounts for the complexity, i.e., the presence of levels of reality more complex than others? It is the thesis that the layers of complexity of nature are distinguished from each other by the ability of the more complex levels to instantiate ontological novelties, that is, unprecedented properties: a given level of nature is more complex than another insofar as it presents emergent properties that are unique at this level, and which therefore were not instantiated in the lower levels of complexity. Otherwise: from a material point of view, each of the levels of nature is composed entirely of the previous level elements; each of these levels presents specific and unique properties; such properties, therefore, were never instantiated. These specific and special properties justify the greater or lesser complexity of a level comparative to a previous or a later one. These kind of properties - which belong to a specific level of reality — are called emergent properties (BEDAU, 1997; BEDAU; HUMPHREYS, 2008; BOOGERD; BRUGGEMAN; RICHARDSON; STEPHAN; WESTERHOFF, 2005; BUNGE, 2003, 2010; CRANE, 2001, EL-HANI; QUEIROZ, 2005a, 2005b; HUMPHREYS, 2008; MCLAUGHLIN, 1992; MOGRABI, 2008, 2016; MORGAN, 1923, 1926, 1933; SAENGER, 2014; SCHOLZ, 2004; SILBERSTEIN, 2002; STEPHAN, 1998, 1999, 2004, 2006; VIEIRA, 2009).

In general, the results of my previous research are consistent with my purpose of supporting a monistic view which — in addition to avoiding the 'tentacles' of all dualistic versions - professes a kind of naturalism which does not merge with the physicalisms, including their non-reductive versions.

The proposal that I have chosen as the purpose of this paper namely, to present the general lines of the stage on which I am developing will be successful carried out, I believe, if three conditions will be performed. The first of these conditions is that I be able to place this step not only within the scope of the general plan of my research, but also to place this research step within the subpart of the research in which it is inserted and to which it belongs: However, I acknowledge that this purpose demands a precise exposition of the relationships held by the present stage with the previous and subsequent steps. The second of these conditions is that I can demarcate the space occupied by the research target of this step within the space occupied by my general research target, that is, that I can demonstrate the insertion of the main problem of this stage in the general problem of my research. Finally, the 
third of those conditions is that I can clearly and distinctly explain my arguments, thereby clarifying and explaining the properly philosophical character of my motivations and arguments; consequently, the third of those conditions is that I can elucidate the philosophical nature of a research which is in principle fostered by interdisciplinary interests and materials.

\subsection{Still the Introduction: On the Need to Reformulate the Physicalist Paradigm}

The theoretical model that I aspire to build will be based on two general and deeply interrelated assumptions, both suggested and encouraged from the results of the current first part of my research project. The first of my assumptions is that (i) the physicalist aspiration to reformulate the dualist theoretical paradigm on which the mind-body problem has been equated since the ancient philosophers did not succeed. Throughout my research and also in the course of this paper, I propose to argue that not only the reductive versions of physicalism but also their non-reductive versions have failed to overcome the dualistic theoretical paradigm (CRANE, 2001b, 2011; VINTIADIS, 2013; GILLETT, 2010). The second hypothesis is that (ii) emergentism is a theoretical orientation based on a (materialistic-monistic) view that has the merit of establishing itself in a new and restored theoretical paradigm, and, in addition, it can be compatible with the best available scientific theories, both those devoted to mapping the relations between mind, body, and environment, and those ones dedicated to scrutinizing the notions of matter and composition of the natural world.

In other words, my general research hypothesis is that many structural, methodological, theoretical and conceptual weaknesses and gaps are shared between reductive physicalisms and classical dualistic perspectives. My answer to this first hypothesis involves an argument whose general lines are the following: on the one hand, the types of materialism most closely related to advances in the brain sciences have contributed significantly to overcome the idea of mind as a substance or a separated property. On the other hand, however, the reductive physicalism has not overcome the dualist paradigm's tendency to dichotomize the physical and mental realms, or even the realms of the brain and body. The development of this hypothesis will be the primary goal of the last production of the first part of my project. Within this communication, I shall confine myself to present the general lines of my position.

The claim that physicalism has not overcome the Cartesian theoretical paradigm is based on a seemingly counterintuitive understanding. In fact, it does not seem reasonable to postulate that physicalism has remained 
within a theoretical framework that has been flawed from its presuppositions. However — and as I want to argue - , the more traditionalist physicalist perspectives remain trapped in the misguided 'logical geography'(RYLE, 1945) inherent to the dualistic paradigm as it was enshrined by Descartes, and especially by Cartesianism. My temporary position for this hypothesis is that the necessary overcoming of this misguided 'logical geography' involves more than the mere relocation of the components of this theoretical framework. Rather, it is necessary the reformulation and/or overcoming this paradigm and its 'logical geography': this is the task that physicalists have promised to carry out; as I propose to defend, however, the physicalists did not succeed in this effort. This complaint is not new, and it connects me to philosophers and scientists of the mind-body problem, such as (among many others) Gilbert Ryle (1945), John Searle (1992), and Antonio Damasio (1994, 1999, 2003, 2010). This complaint also draws me closer to the group of philosophers, psychologists, biologists and cognitive scientists who support embodied cognition theory, in the wake of Varela, Thompson and Rosch's seminal work (1991). Through such complaint, I am also in proximity with the recent group of philosophers, psychologists and cognitive scientists who are engaged with the theories on the relations between self-consciousness and bodily awareness mechanisms, like Bermúdez (2005, 2011), Cassam (2011), Gallagher (1986, 1995, 2003, 2005, 2011), Henry and Thompson (2011), Legrand (2006, 2007, 2011), O'Shaughnessy (1995), Tsakiris (2010, 2011), Vignemont (2005, 2007, 2010, 2011a, 2011b, 2011c, 2012), and many others.

My answers to my research hypotheses are consistent with those aforementioned theoretical orientations and researchers. With regards to my research hypothesis (i), I wish to support the thesis according to which the physicalist holds the dualistic dichotomy between the physical and the mental, albeit with new appearance. This dichotomization is observed in the reduction, inasmuch as the reduction implies a relationship between two or more 'entities'.

This is the reason why it is common the elimination of the mental by physicalists, such as expressed in all known reductionist strategies: I believe that this attitude is the mistaken alternative to which physicalists resort in order to try to eliminate the classical mind-body dichotomization. However, this alternative does not redeem the physicalist of the paradigm against which it is directed. Here's the problem: this paradigm to which I am referring will always engender dichotomizations; in place of the classical dualistic conception and of the dichotomization between physical substances (bodies) and nonphysical substances (the mental), physicalism appeals to a split-up between the brain and the mind, on the one hand, and, on the other hand, between the 
body proper and the environment. In the most radical physicalists approaches, the dichotomization between the brain and the mind is proposed, just as it is within classic dualisms. This dichotomization is clearly expressed in a formula which is problematic only for a dualist paradigm: "if something is physical, it cannot be mental; if something is mental, it cannot be physical".

As I propose to argue, the reductivist thesis about the identity between types of mental states or mental events and types of brain states or physical events does not break away from the dichotomization between opposites (at least on the discursive plane), with frequent ontological splits between the mental and the cerebral, that is, between the mental sphere and the bodily/physical one. This view - against which I will position myself arises from the physicalist affiliation to a theoretical paradigm that does not envisage ontological possibilities beyond the notions of mental and physical as distinct realms. In view of the present scenario, the reductive solution has been to deny or at least to reduce mind to brain. Within this scenario, it can be said that reductive physicalism is betrayed by a vocabulary and, consequently, by a set of concepts that they unwittingly borrow from the dualistic paradigm. Indeed, the significant progress in the history of the mind-body problem from the delineation of the causal nexus between brain, mental states and behavior has failed to promote the disappearance of the dualistic division of mind and body within the scientific and materialist philosophical circles. Based on the belief that the brain itself is sufficient to elucidate the emergence and structuring of the mind, physicalism has merely changed the exact point upon which the Cartesian dualism focuses.

The restriction of the physicalists to the dualistic paradigm is expressed whenever:

(i) Reductive physicalists in general disregard the reality of phenomena that do not fall into the category of substances, such as what I mean by processes, properties and/or higher-level features. In fact, the reductive paradigm rules out the existence of any entities beyond the dichotomy between material and immaterial, reducing the totality of things to a dichotomy between, on the one hand, (i) the entities - that is, the group of existing things, expressed in everything that is endowed with material substance and, on the other hand, the notions that do not correspond to existing entities, such as any immaterial substances;

(ii) Reductive physicalists reject the understanding that mind and brain are two different levels of a same stratified reality, which corresponds to a reductive interpretation of the idea that the mind is nomologically dependent on the brain. The emergentist claim that the mind is a component reality of the physical world is not interpreted the same way by reductivists. The reductivist 
project is based on a worldview in which the reality is divided between things (material substances) and non-things (immaterial substances). Thus, the view of nature grounded in a hierarchy of natural processes is definitely rejected by reductivists. The reductivists thus cannot account for the characteristics or processes which are beyond the dichotomization between things and nonthings. Reductivists therefore cannot explain the higher-level processes and features to which I referred in (i);

(iii) Reasons (i) and (ii) associated exposes the rejection of reductionist physicalists to the idea that the mind is independent and autonomous in relation to the body: for reductive physicalists, this thesis implies admitting the existence of two distinct substances. Therefore, it is natural that physicalists disregard the emergentist argument according to which the mind is an emergent and autonomous property in relation to the behavior of the parts (such as the brain and/or the body, or even their most crucial parts for the emergence of the mind). Physicalism therefore goes against the (emergentist) thesis according to which the autonomy of mental properties does not exclude the nomological dependency of the emergent properties or mental phenomena with respect to the basic properties and/or the behavior of the system's parts.

If, as I wish to argue, reductive physicalism incurs in (i), (ii) and (iii), then the project of reducing the mind to the brain (or body) is not limited to the rejection of any kind of autonomy of the mind in relation to the body (or brain). Rather, the reduction project seems to imply the very negation of the 'reality' of the mind. This is the reductionist conception according to which mental states are numerically identical to brain states. Indeed, the efforts of empirical research find more fertile ground in the investigations of the behavioral correlates of brain activity. From all this, physicalists conclude though not always explicitly — that references to mind are justified only for the communication purposes on which popular psychology is based. So there is no ontological or epistemic role to mind. I disagree with these reductivists implications. In the place of these view, I will propose to argue that these results stem from a framework which is based on fragile theoretical foundations.

The present moment of my research is therefore driven by the understanding that the various brain sciences require a paradigmatic reformulation of the framework on which the most varied forms of problematizing the mind-body relationship are based. This understanding is an important reason for my affiliation to an emergentist view of the mind-body problem. 
Given, however, that the basic principles of emergentism are not sufficient to support an independent monistic view of physicalism, it is necessary that I seek to outline, in line with Stephan (1998, 1999, 2004, 2006), the principles through which the monism of the emergentists is not confused with the reductionist monism of the physicalists.

It is true, however, that the present paper does not have enough space to advance in the study of the reasons that lead me to the rejection of the principles that physicalist assimilated of the reductionist program that subsidizes the natural Sciences in general. However, a minimal presentation of these principles is necessary so that I can advance the ideas I proposed to develop throughout this paper:

(i) the natural world is structured in a physical unity thanks to which: (a) all existing entities - from simple to complex, from inorganic to organic - can be explained by the Principle of Composition of Causes ${ }^{3}$ (there is only one type of objects and/or properties in the world); (b) there is only one legitimate science, the physics: all others sciences — the so-called special ones - are only special cases of the physics;

(ii) the behavior of the wholes or composite systems can be nomologically deducted from the behavior of their parts (or from their basic elements), and therefore we can deduce the wholes laws from their parts laws; in other words, the whole is derived entirely from those parts and their interactions;

(iii) the intertheoretical reduction of a theory to another one is always expected, and takes place through bridge laws — which happens for example in the relationship between psychology and neurosciences. From this understanding follows the view that higher-level theories are additively structured from lower-level ones;

(iv) synonymy between reduction and explanation, resulting in the the understand that every scientific explanation is reductive; and, among many others,

(v) numerical identity between types of mental states and types of neural states or even between mental and physical events, from which it follows the thesis that mental states are reducible to neural states.

It is true that the best available physical theories support a monist thesis, that is, the thesis according to which entities existing or coming into being in the universe consist solely of physical constituents, ie, entities consist only of material parts. Although I agree with physicalists in this regard, my

${ }^{3}$ Principle of Composition of Causes is the term used by John Stuart Mill (1843) to refer to the idea that effects of causes are always additive. 
theoretical position on the constitution of the natural world seeks to overcome the paradigm of the physicalist dichotomization - inherited from the Cartesian frame of reference. I will try, therefore, to be beyond a worldview established by a mere dichotomy between, on the one hand, material entities, that is, entities that are reducible to fundamental particles and, on the other hand, immaterial ones, ie, the non-existent class. In this sense, I am in agreement with the emergentist position that it is necessary to overcome the classic way of understanding the organization of the natural world, particularly the idea that everything is reducible to ultimate constituents of matter, the socalled elementary particles.

In place of the reductionist understanding on the organization of the natural world, I will seek support - in line with the emergentists - a set of theoretical principles that intend to harmonize a layered view of nature with a wholly monistic ontological perspective. These principles are: (i) the nature is stratified into different layers or levels of complexity, thanks to selforganization processes of the natural world; (ii) there are properties that are systemic and, in addition, emergent ones; (iii) emergent properties present novelties im relation to the sum of the parts; and, among others, (iv) emergent properties may not be reduced to behaviors, or to processes and laws of the system's parts, either when those parts are isolated or they are in other (types of) groups.

At this time, therefore, my main motivation consists in offering an alternative to a mechanicism, a view of nature that inherits from atomism (classic and modern) the conception that all entities are explained by the principle of Composition of Causes. This purpose is at the service of my intention to converge the two principles that, as I want to defend, are only apparently contradictory, namely: (i) phenomena or emergent properties are continuous with respect to the underlying processes from which they emerged; and, (ii) emergent entities are new and autonomous (and, thus, somewhat discontinuous) in relation to the components and processes from which they emerged.

\section{The role of atomism and mechanism in physicalist conception of the world}

The reductionist program goes back to the doctrines of the Greek atomism - Leucippus, Democritus and Epicurus - concerning the structure and the constitution of matter and the physis, or, in other words, on the micro and macro-structure of the natural world. Under the influence of Greek atomism, it may be explained why the discussion of the ultimate foundation of reality so pervades contemporary metaphysics. More than this, it is the role 
played by the assimilation of classical Greek atomism by contemporaries which explains which explains the contemporary strength of the fundamentalist position, that is, of the striking presence of the believe that it is legitimate to refer to an ultimate foundation of reality. For obvious reasons, this position is very sympathetic to the reductionist program in its intention to establish numerical identities which point to fundamental levels. As Schaffer (2003, p.498) points out, there are four general forms of taking a fundamentalist position: (i) the physicalist position, according to which only the fundamental level entities are primarily real: composite entities are only derivative; (ii) the Humean one, according to which everything supervenes on the local distribution of the fundamental qualities; (iii) the epiphenomenalist position, in accordance with which all causal powers date back to the fundamental level; and (iv) the atomistic one, according to which there are no macroentities, but only fundamental entities, which arrange and group themselves in many ways.

In a discussion of the relations between reduction and fundamentality, Murphy (2007, p.23) ascertains features of atomism in various modern and contemporary forms of reduction, all closely interrelated: (i) in the methodological reductionism. It is a form of research strategy which consists of analyzing objects through the investigation of their parts; (ii) in the epistemological reductionism. This is the idea according to which the laws and higher level theories result from lower-level layers, laws, and theories, especially from the physical realm, and its own science, the physics; (iii) in the logical or definitional reductionism, according to which the words and sentences which refer to a type of entity can be translated into a language about another type of entity without residues; (iv) in the causal reductionism, under the thesis that the behavior of the system's parts determines the behavior of the higher-level entities; (v) in the ontological reductionism, within the thesis that the higher-level entities are no more than the sum of their parts. Also according to Murphy (2007, p 23-24), ontological reductionism is divided into two general approaches, namely: (v.a) the conception that new material ingredients are not added in the hierarchy of levels of reality (ontological reductionism itself), and (v.b) the more radical conception according to which only the basic entities are real, so that the compounds (cells, molecules, and organisms) are nothing more than complex groups of atoms (this approach is equivalent to reductionist atomism).

Murphy (2007, p.24) also argues that the level of interrelationship between reductionist approaches are quite revealing: from the truth or the acceptance of the atomistic reductionism follows the truth or the need for acceptance of all other forms of reductionism. This is the reason why atomistic reductionism is the source of all other forms of reductionism (MURPHY, 
2007, p.24), which implies that reductionisms are characterized by the causal priority of atoms (or any other designation we may offer to elementary particles). In fact, although the reverberation of atomism in physicalism has been seldom discussed, the believe in a fundamental level of reality is widely shared by physicalists (SHAFFER, 2003, p.499). A paradigmatic example of this belief is found in the defense of the fundamentality by two of the most prestigious thinkers of the twentieth century, Paul Oppenheim and Hilary Putnam (1958). In one of the most important books (1958) written in the twentieth century about the possibility of unity of science, Oppenheim and Putnam have defended the fundamentality of the lower level, i.e., the elementary particles level. It is at this fundamental level that is found the 'space' to which all entities refer to, and where lies the key to the unification of the sciences, via micro-reduction.

The seventeenth century is the moment when the mechanistic materialism reaches its apex; the various versions of mechanistic materialism of this time are marked by the defense of a concept of matter and nature that was vigorously enforced between the 1600s and 1850s. In general, classical mechanism is marked by the aspiration to reduce all physical phenomena to a theoretical paradigm limited to matter, movement, and primary qualities: with respect to primary qualities, it is the extension, to Descartes; the greatness, figure and movement, for Galileo; the extension, form, impenetrability, and move, to Robert Boyle; the extension, hardness, impenetrability, mobility, and inertia, to Newton (ABRANTES, 1998, p.60; BEZERRA, 2006, p.179).

In the reduction of physical phenomena to this theoretical framework - within a mechanistic conception of nature - arises a view of nature that Bezerra (2006, p.179) calls the ontological sense of mechanicism. This ontological sense of mechanism implies the following theses: (i) the matter is essentially passive; (ii) the physical world is provided with a homogeneous nature; (iii) any action occurs by contact, or even, there is no action at a distance; (iv) material bodies are driven exclusively by collision/interaction with other material bodies; ( $v$ ) if there is causality, it is restricted to efficient causes (BEZERRA, 2006, p.179). Mechanism - conceived from a methodological and epistemological point of view — implies the belief that all physical phenomena are amenable to mechanical explanations, within the quite comprehensive view that all things function as machines (BEZERRA, 2006, p.180).

The relevance of mechanicism to my purposes is due to the fact that some of its principles still resonate in our time. It concerns the idea that nature — which includes not only all entities but all their relations — is completely reducible to fundamental particles, and, moreover, obedient to natural 
mechanical laws. In addition to this understanding, mechanistic materialism advocates the existence of a single kind of matter, whose properties are generally defined as: extension, mass, shape, and mobility (BUNGE, 2010, p.25). Given these general understandings, mechanistic materialism conceives the continuity as one of the universal features of the nature: This is about the understanding that all changes in nature are mere increments, which do not imply, in any instance, discontinuity, such as emergent properties. The continuity governs the relationship between entities with different level of complexity, so that all property is resulting, and never emergent. One of the universal features of the matter is the passivity: that is why all changes that occur in a material object arises outside of it. In addition to the notion of inertia, stability is one of the most important corollaries of the notion of passivity: material things are modified thanks to external forces and/or internal tensions. This means that mechanistic materialism also excludes the possibility of selforganization in the material world (BUNGE, 2010, p.29). In effect, mechanistic materialism denies the set of facts to which the principles of selforganization refer. The principles of self-organization have been widely attested by the various empirical sciences of nature, and they are consistent with the experimental reality of all scales of biological organization (KURAKIN, 2007).

Indeed, from the most remote formulation of atomism - by Leucippus and Democritus, and even during the time when atomism gave way to Aristotelianism - since Aristotle held that the universe is completely filled by matter — it has become customary to conceive the natural world as composed of simple, elementary, and subsistent corpuscles, being thus objective and governed by mechanical laws, with no room for selforganization. Since then, it has also become customary to conceive that all complex beings are formed by additive processes, that is, by the composition of causes, which certainly excludes the possibility of emergent properties. Indeed, properties which are fully explained by the principle of Composition of Causes are always resulting properties. 'Resulting properties', contrary to emerging properties, are reducible to the behavior and properties of the parts of the systems from which they result.

\section{For a Physicalism based on complexity and on the irreducibility of emergent properties}

From the nineteenth century onwards, the worldview supported by mechanicism has undergone numerous blows from the most diverse fields of study dedicated to the investigation of the structure of matter and nature, among which field theory, electromagnetism, research on chemical synthesis, 
embryology, in addition to studies in biological and social evolution (BUNGE, 2010, p.73). One of the most remarkable reformulations undertaken by this recent and prolific history of science consists in a new understanding of matter: instead of the idea of matter as a passive substance, it is now the understanding that the matter is subject to self-organization processes (BUNGE, 2010, p.73). In this scenario, it is also remarkable the understanding that the composition is essential but not sufficient in the sciences to explain the emergence of new and more complex entities in nature: indeed, bottom-up analysis - as proposed by composition method — should be complemented with top-down analysis. Like all systems that organize themselves, the internal organization of matter can be constituted and modified itself without the interference of external agents, which means, because of the interaction between its own internal elements (SCHOLZ, 2004, p.18).

The consequences of this turnaround - well understood by Bunge (2010, p.73-75) — is the neuralgic point of my interest: composition remains essential to physics and, consequently, to the physical basis of philosophy of mind, but is not sufficient to explain the appearence/emergence of new and more complex entities in nature. In order for us to fully understand the structure of wholes in the natural world, we must rely on the notions of structure and mechanism (BUNGE, 2003, BUNGE, 2010, p.73). (BUNGE, 2003, BUNGE, 2010, p.73). It follows that analysis or decomposition are scientific methods that are necessary and yet insufficient to capture the wholes: bottom-up analyzes must be complemented with top-down ones (BUNGE, 2010, p.74).

It is about a new understanding, namely: complex systems are constituted as a higher-level emergent organizational pattern which determines — by dynamic selection — the parts allowed within the system; moreover, this organizational pattern regulates and restricts the particular behaviors and the processes of the lower-level components. In other words, the lower-level components depend on the higher-level properties, since the organizational pattern also changes the relations that the parts have with each other, as well as modify the causal powers of the parts themselves. Systems become complex through positive feedback processes between higher-level characteristics and their base components, this means that the product of the process - in our case, the emergent properties - determines the process itself since the activity of its bases (VIEIRA, 2009, p.28-29). The higher-level organizational pattern is characterized by properties that are not reducible to the sum of lower-level components: in the properties that characterize the organization at the system level, there are no new material ingredients; however, with regard to the world 
ontology, the organizational pattern displays additional novelties, which are irreducible to the level of which they emerge.

The increasing and progressive overthrow of the mechanistic paradigm implies the simultaneous overthrow of the physicalist worldview, insofar as mechanism and physicalism are not compatible with the implications of the twists and turns of the worldview that emerged after the standard mechanistic decline. In other words, the increasing and progressive overthrow of the mechanistic paradigm implies the overthrow of the following theses: (i) the universe is constituted on a single level, i.e., the level of physical things; (ii) entities are composed exclusively of bits of matter; (iii) it is possible to elaborate a theory of everything within a unifying theoretical frame of reference (BUNGE, 2010, p.74).

The reductive assimilation of the atomistic program is characterized by the intention to explain the whole through its parts. This scientific and philosophic phenomenon was marked by a lot of failures in trying to deduce - via bottom-up analyzes - the 'behavior of the whole' from the sum of the system (that is, the whole) parts. This collection of failures, widely registered in scientific manuals and textbooks, made room for the understanding according to which the behavior of the parts is influenced by position they occupy in the whole and by the relationships they have with other parts within this whole, which involves the influence of the system in relation to its own parts. In other words, the decline of mechanicism was followed by the fruitful possibility of replacing the reduction and strict observance of the analytical and decompositional method by a cross-level research (BUNGE, 2010, p.74).

A favorable or unfavorable position on the fundamentalist status of physicalism can be supported in the previous (or simultaneous) position that is assumed in relation to two general questions. At the ontological level, the question is: can it be said that all existing entities are determined by a composition of the fundamental constituents (elementary particles) of reality? At the epistemological level, the question is: can scientific theories/schemes about the macroscopic characteristics of the world be reduced to theories about the basic elements of nature? (SILBERSTEIN, 2002, p.80). The philosophical benefits derived from these questions are due to the fact that, in general, the mechanistic and reductionism paradigms converge on the positions taken on these issues. Although in principle there is no correlation between the reductionism and the mechanistic paradigm, reductive physicalism tends to profess the idea that complex systems are seized at the level of (a) behavior, of (b) their relationships, and of (c) the laws of their component parts; more than that, it tends to profess that the very relations between the parts are reducible. In this sense, an opposition to mechanism involves the 
rejection of the reductionist program and of the physicalists theories which are grounded in axial principles of reductionism.

From the ontological point of view, this means that the physical level is the fundamental level, and that it is at this level that the entire ontological structure of reality resides: the whole real points to this basic level (SILBERSTEIN, 2002, p.81). From the epistemological point of view, this means that there is the possibility of constitution of a fundamental theory which is capable of offering a complete knowledge of the world, and therefore that is possible to think of a theory of all things within which the mind, a mammal, a protozoan and a piece of stone are treated within the same explanatory framework. As I have tried to argue, my view is associated with neglect of the understanding that the mind is a property of brains composed of living tissues (BUNGE, 2010, p.vii).

In this sense, an opposition to mechanicism involves a rejection of the reductivist program as well as of the physicalisms based on the axial principles of reductionism. The weariness of the reductionist program which underlies the the innumerable non-reductive physicalism versions was followed by the weariness of the mechanicism, although reductivism is still very popular in philosophical circles.

Throughout my research, I have tried to support that there is just one theoretical orientation that is able to support a monistic position and (at the same time) to avoid the weaknesses and structural, methodological, conceptual and theoretical gaps of the reductive physicalism: it is about the emergentist. An emergentist essential component to perform the reformulation of the reductive paradigm involves the understanding that the nature is divided into an organizational complexity levels of hierarchy. This hierarchy extends itself from the level of elementary particles - the level at which physics is addressed - to the psychological level, or even to the social institutions one.

What it is now at stake is the following set of ideas: On the one hand, the nature is composed entirely of elements, processes, and physical force fields. Moreover, the nature is divided into different levels of complexity. Each of these levels consists of the same elements that make up the previous level. However, each of these levels has specific properties, i.e., properties not instantiated in the previous level. These properties indicate the complexity index of a level relative to a previous or a later. Finally, these special properties inhere to a specific level of reality, and they are called emergent properties (BEDAU, 1997; BEDAU; HUMPHREYS, 2008; BOOGERD; BRUGGEMAN; RICHARDSON; STEPHAN; WESTERHOFF, 2005; BUNGE, 2003, 2010; CRANE, 2001, EL-HANI; QUEIROZ, 2005a, 2005b; HUMPHREYS, 2008; MCLAUGHLIN, 1992; MOGRABI, 2008, 2016; 
MORGAN, 1923, 1926, 1933; SAENGER, 2014; SCHOLZ, 2004; SILBERSTEIN, 2002; STEPHAN, 1998, 1999, 2004, 2006; VIEIRA, 2009).

In fact, the conception of hierarchical organization has become a commonplace in the sciences, and in the philosophical treatment of the structure of scientific disciplines (POTOCHNIK; MCGILL, 2012, p.120). However, such a conception was unable to settle the fundamentalist position, especially among physicalists who do not necessarily advocate the unity and simplicity of the world's structure. As Schaffer (200, p.498) warns, the starting point of the fundamentalism and the fundamentalists in general is the hierarchical understanding of nature in terms of its stratification into levels. In this sense, emergentists are distinguished from physicalists by the rejection of the first ones regarding the possibility of reduction to a final and fundamental level of the nature.

In such an understanding of nature, is implicated the view according to which complex entities 'are more than the sum of their basic parts', or, to be more precise, complex entities are not explained from the analysis of their parts. Consequently, it is also implied that each of the existing objects and every experienced phenomena occupies a 'specific place' within a hierarchy which is implicitly determined by the organizational complexity of the objects: as well as each of those level contains objects and properties that are not found in levels previous, each of these level requires a particular science (BEDAU, 1997; BEDAU, HUMPHREYS, 2008, p.5).

\section{Final Remarks}

At the end of this short paper, I hope that the brief description of my position regarding the diversity of complexity levels of nature and the irreducibility of emergent properties may support the following additional clarification: my opposition to the reductivist program rests on the same grounds as my thesis that a science of the nervous system does not have the necessary resources to support a supposed (conscious) mind science. With regard to this point, my arguments focus on the following understandings: Psychology can be defined as the science that deals with mental properties, and mental properties emerge from the body. On this point, my arguments focus on the following understandings: Psychology can be defined as the science that deals with the mental properties which emerge from a functioning living organism (body). Here, in this sense, I have tried to defend: in comparison to psychology, a science exclusively dedicated to the body is related to less complex objects, although there is no addition of material ingredientes in the latter. Consequently, I have proposed to argue that a science of bodily properties deals with properties and laws which are different from those with 
which psychology deals, although both deal with the same materials ingredients.

For all that I have said, my thesis according to which the emergence of the mind is a function of the higher-level organizational principle of organisms endowed with sufficiently complex nervous systems implies: first, the notion that (i) the mind is a higher-level organizational pattern which determines possibilities for particular processes and behaviors of lower-level. On the other hand, this is also the understanding that (ii) organisms with nervous system are adaptive systems become complex through positive feedback processes. These processes occur between higher-level features and the basic componentes of the systems. This means that the product of the process (emergent properties) determines the process itself since the activity of its bases. It is in this sense I propose to argue that the referral to the problem of mind-body relationships involve the notion of 'circular causality' (or selfcausation) between mental properties and the components of a system which is integrated by brain, body, and environment. Finally, it is the understanding that (iii) the higher-level organizational pattern is characterized by the emergence of properties that are not reducible to the sum of the lower-level componentes; these properties reveal the higher-level organization of the system: in the properties that reveal the organization at the system level, there is no new materials ingredients; from the standpoint of 'the world ontology', however, the organizational pattern displays irreducible and unprecedented properties.

That is why emergentist research program should be to outline the reasons to support the thesis that mental properties are systemic properties, and that these properties are found only at the system level as a whole, and not at the level of the parts. Such a program is less simple than it seems, because it must converge with principles which, at first glance, are compatible with reductive physicalism, namely: the principle of (i) physical monism, according to which all properties, dispositions, behaviors, and structures which are classified as emergent are instantiated by systems consisting exclusively of physical entities; the principle of (ii) systemic (or collective or organizational) properties, according to which emergent properties are systemic ones, and that systemic properties are properties which are found onty at the system level, ie, no part of the system possesses it; and, third, the principle of (iii) synchronic determination of properties in relation to its parts, according to which the properties, the behaviors or dispositions to behave, and the rules of a system depend nomologically on its microstructure, ie, on its parts' properties and their arrangement. This is the idea according to which "there can be no difference in the systemic properties without there being some differences in 
the properties of the system's parts or their arrangement" (STEPHAN, 1998, p.641).

In other words, the problem for emergentist is as follows: given the convergence between the emergentist principles and the best available theories of physics, the emergentist perspective shows remarkable affinities with reductive physicalisms. Such an affinity is emphasized when we closely consider the basic principles of emergentism, especially physical monism and determination synchronic principles. The same happens when we observe that physicalism converges with emergentism in professing its philosophical defense concerning the existence of different levels of complexity in nature. It is no accident that the emergentism only differs from physicalism by adding additional arguments in relation to three basic theses.

On the other hand, however, emergentism differs on some dimensions from physicalism. This divergence occurs when, for example, emergentists argue that the material continuity throughout the various levels of the nature does not impair the discontinuity of new properties compared to previous levels. The emergentism differs sharply from the physicalism when it argues that the properties of a level can not be reduced to the properties of the previous level: according to the emergentist, the irreducibility relationship between diferente levels of properties is what most characterizes the connection between mental properties and neural properties. After all, mental properties are identified by irreducibility, and, therefore, cannot be subject to a physical science. Although the distinctions between emergentism and reductive physicialisms are very significant, they are also very subtle, which make them difficult to grasp. It is because of this last reason that the emergentism is often confused (in an equivocal manner) with one of the forms of dualism. Such a difficulty, I believe, is due to the fact that a solid emergentist perspective is established in a completely strange theoretical paradigm with regard to one in which we have been educated. Undoubtedly emergentist research program is, at least, thought-provoking and challenging.

\section{References}

ABRANTES, Paulo. Imagens de natureza, imagens de ciência. Campinas: Papirus, 1998.

BEDAU, Mark. "Weak emergence". In: Philosophical Perspectives, v.11, p.375399, 1997.

; HUMPHREYS, Paul. "Introduction". In: BEDAU, Mark A.; HUMPHREYS, Paul (Eds.). Emergence: Contemporary Readings in Philosophy and Science. Cambridge, MA; London, UK: The MIT Press, 2008, p.127-144. 
BERMÚDEZ, José Luis. "The phenomenology of bodily awareness". In: SMITH, David Woodruff; THOMASSON, Amie. Phenomenology and philosophy of mind. Oxford: Clarendon Press, 2005, p.295-316.

. "Bodily Awareness and Self-Consciousness". In: GALLAGHER, Shaun. The Oxford Handbook of the Self. Oxford, UK: Oxford University Press, 2011, p.157-179.

BEZERRA, Valter Alnis. Maxwell, a teoria do campo e a desmecanização da física. Scientiae Studia: Revista Latino-Americana de Filosofia e História da Ciência, v. 4, n. 2, p. 177-220, 2006.

BOOGERD, Fred C.; BRUGGEMAN, Frank Johannes; RICHARDSON, Robert. C.; STEPHAN, Achim; WESTERHOFF, Hans V. "Emergence and Its Place in Nature: A Case Study of Biochemical Networks". In: Synthese, v.145, n.1, 2005, p.131-164.

BUNGE, Mario. Emergence and convergence: Qualitative Novelty and the Unity of Knowledge. Toronto, ON: University of Toronto Press, 2003.

Matter and Mind: A Philosophical Inquiry. Dordrecht/Heidelberg/London/New York: Springer Netherlands, 2010 [Boston Studies in the Philosophy of Science, v. 287].

CASSAM, Quassim. "The Embodied Self. In: GALLAGHER, Shaun. The Oxford Handbook of the Self. Oxford, UK: Oxford University Press, 2011, p.139156.

CRANE, Tim. "The significance of emergence". In: GILLETT, Carl; LOEWER, Barry (Eds.). Physicalism and its discontents. Cambridge, UK: Cambridge University Press, 2001, p.207-224.

. Interview with Tim Crane: entrevista [2011]. São Paulo: Interview to Praxis Journal of Philosophy, 2011.

DAMASIO, Antonio. Descartes's Error: Emotion, Reason, and the Human Brain. New York: Putnam's son, 1994.

. The Feeling of What Happens: Body and Emotion in the Making of Consciousness. Heinemann: London, 1999

. Looking for Spinoza: Joy, Sorrow, and the Feeling Brain. New York: Harcourt, 2003.

. Self Comes to Mind: Constructing the Conscious Brain. New York: Vintage Books, 2010. 
EL-HANI, Charbel Niño; QUEIROZ, João. "Modos de Irredutibilidade das Propriedades Emergentes”. In: Scientiae Studia, v.3, n.1, p.9-41, 2005 a.

192, 2005b. . "Downward determination". In: Abstracta, v.1, n.2, p.162-

GALLAGHER, Shaun. "Body Image and Body Schema: A Conceptual Clarification". In: Journal of Mind and Behavior, v.7, p.541-554, 1986.

. "Body Schema and Intentionality". In: BERMÚDEZ, José Luis; MARCEL, Anthony; EILAN, Naomi (Eds.). The Body and the Self. Cambridge, MA: MIT Press, 1995, p.225-244.

. "Bodily Self-Awareness and Object-Perception". In: Theoria et Historia Scientiarum: International Journal for Interdisciplinary Studies, v.7, n.1, p.53-68, 2003.

2005.

. How the Body Shapes the Mind. Oxford, UK: Oxford University Press, (Ed.). The Oxford Handbook of the Self. Oxford, UK: Oxford University Press, 2011.

GILLETT, Carl. "On the Implications of Scientific Composition and Completeness: Or, The Troubles, and Troubles, of Non-Reductive Physicalism". In: Corradini, Antonella; O'Connor, Timothy (Eds.). Emergence in Science and Pbilosophy. New York, NY: Routledge, 2010, p.25-45.

HENRY, Aaron; THOMPSON, Evan. "Witnessing from Here: SelfAwareness from a Bodily versus Embodied Perspective". In: Gallagher, Shaun. The Oxford Handbook of the Self. Oxford, UK: Oxford University Press, 2011, p.228-252.

HUMPHREYS, Paul. "How Properties Emerge". In: Bedau, Mark A.; Humphreys, Paul (Eds.). Emergence: Contemporary Readings in Philosophy and Science. Cambridge, MA; London, UK: The MIT Press, 2008, p.111-126.

KURAKIN, Alexei. The universal principles of self-organization and the unity of Nature and knowledge. Available at: <http://www.alexeikurakin.org/text/thesoft.pdf>. Accessed on February 01, 2017.

LEGRAND, Dorothée. "The bodily self: The sensori-motor roots of prereflective self-consciousness". In: Phenomenology and the Cognitive Sciences, v.5, p.89-118, 2006.

. "Subjectivity and the body: Introducing basic forms of selfconsciousness". In: Consciousness and Cognition, v.16, p.577-582, 2007. 
. "Phenomenological Dimensions of Bodily Self-Consciousness". In:

GALLAGHER, Shaun. The Oxford Handbook of the Self. Oxford, UK: Oxford University Press, 2011, p.205-227.

LENT, Roberto. Cem Bilhões de neurônios: conceitos fundamentais de neurociências. São Paulo: Atheneu, 2010.

MACHADO, Ângelo. Neuroanatomia funcional. São Paulo: Atheneu, 2006.

MCLAUGHLIN, Brian. "The Rise and Fall of British Emergentism". In: Beckermann, Ansgar; Flohr, Hans; Kim, Jaegwon (Eds.). Emergence or Reduction?: Essays on the Prospects of Nonreductive Physicalism. Berlin, Germany: Walter DeGruyter \&Co., 1992, p.19-59.

MOGRABI, Gabriel José Corrêa. Emergência, Mente e Decisão: A Relevância Causal de Diferentes Niveis. 2008. 332 p. Thesis (PhD in Philosophy) - Federal University of Rio de Janeiro, Rio de Janeiro, RJ, 2008.

. "O Monismo Físico e a opção dinâmica - ou, por um Fisicalismo de Forças ou Interações como melhor opção na lida com o 'Dilema de Hempel”". In: Princípios: Revista de Filosofia, v.23, n.40, p.97-126, 2016.

MORGAN, Conwy Lloyd. Emergent Evolution. London, UK: Williams and Norgate, 1923. . Life, Mind, and Spirit. London, UK: Williams and Norgate, 1926. . The Emergence of Novelty. New York, NY: Henry Holt and Co., 1933.

MURPHY, Nancey. "Reductionism: How did we fall into it and can we emerge from it?". In: Murphy, Nancey; Stoeger, William R. (Eds.). Evolution and Emergence: Systems, Organisms, Persons. New York: Oxford University Press, 2007, p.19-39.

OPPENHEIM, Paul; PUTNAM, Hilary. "The Unity of Science as a Working Hypothesis". In: Feigl, Herbert; Scriven, Michael; Maxwell, Grover (Eds.), Minnesota Studies in the Philosophy of Science, v.2. Minneapolis, MN: Minnesota University Press, 1958, p.3-35.

O'SHAUGHNESSY, Brian. "Proprioception and the Body Image". In: Bermúdez, José Luis; Marcel, Anthony; Eilan, Naomi. The Body and the Self. Cambridge, MA: MIT Press, 1995, p.175-203.

POTOCHNIK, Angela; MCGILL, Brian. "The Limitations of Hierarchical Organization”. In: Philosophy of Science, v.79, n.1, p.120-140, 2012.

RYLE, Gilbert. The Concept of Mind. London: Hutchinson \& Company, 1949. 
SAENGER, Victor M. A Matter of Mind: Reductionism and Emergentism as frameworks for understanding Consciousness. 2014. 26 p. Dissertation (MA in Neurosciences and Cognition) - Utrecht University, Utrecht, The Netherlands, 2014.

SANTOS, Cláudio Guimarães dos. Plasticidade Neuronal: Interview [03 October, 2011]. São Paulo: Dr. Drauzio. Interview. Available in: $<$ http://drauziovarella.com.br/envelhecimento/plasticidade-neuronal/>.

SCHAFFER, Jonathan. "Is there a fundamental level?" In: Nous, v.37, n.3, 2016.

SCHOLZ, Jan. Emergence in cognitive science: Clark's four proposals to the emergentists. Osnabrück, BS: PICS, 2004. [Publication Series of the Institute of Cognitive Science, v. 10].

SEARLE, John. The Rediscovery of Mind: Representation and Mind. Cambridge, MA: Bradford Book, 1992.

SILBERSTEIN, Michael. "Reduction, Emergence and Explanation". In: MACHAMER, Peter; SILBERSTEIN, Michael. The Blackwell Guide to the Philosophy of Science. Malden, MA: Wiley-Blackwell, 2002, p.80-107.

STEPHAN, Achim. "Varieties of Emergence in Artificial and Natural Systems". In: Zeitschrift für Naturforschung: a Jornal of Biosciences, v.53c, p.639656, 1998. 59, 1999.

. "Varieties of emergentism". In: Evolution and Cognition, v.5, n.1, p.49-

"Phenomenal Emergence". In: Networks. Rivista di filosofia dell'intelligenza artificiale e scienze cognitive. A journal of the philosophy of artificial intelligence and cognitive sciences, v.3, n.4, p.91-102, 2004.

. "The Dual Role of 'Emergence' in the Philosophy of Mind and in Cognitive Science”. In: Synthese, v.151, n.3, p.485-498, 2006.

TSAKIRIS, Manos. "My Body in the Brain: a Neurocognitive Model of BodyOwnership". In: Neuropsychologia, v.48, n.3, p.703-712, 2010.

. "The Sense of Body Ownership". In: Gallagher, Shaun. The Oxford Handbook of the Self. Oxford, UK: Oxford University Press, 2011, p.180-203.

VARELA, Francisco; THOMPSON, Evan; ROSCH, Eleanor. The Embodied Mind: Cognitive Science and Human Experience. Cambridge, MA: MIT Press, 1991. 
VIEIRA, Fabiano de Souza. Determinação Descendente: A Relação todo-partes em Sistemas Naturais. 2009. 116 p. Dissertation (MA in Teaching, Philosophy and History of Sciences) - Federal University of Bahia, Salvador, BA, 2009.

VIGNEMONT, Frédérique. "Body Mereology". In: Knoblich, Gunther; Thornton, Ian; Grosjean, Marc; Shiffrar, Maggie. Human body perception from the inside out. New York: Oxford University Press, 2005, p.147-170.

. "Habeas Corpus: the sense of ownership of one's own body". In: Mind and Language, v.22, n.4, p.447-449, 2007.

. "Frédérique. Body Schema and Body Image: Pros and Cons". In: Neuropsychologia, v.48, n.3, p.669-680, 2010.

. "Bodily Awareness". In: Zalta, Edward. The Stanford Encyclopedia of Philosophy. Disponível em:

$<$ http://plato.stanford.edu/archives/fall2011/entries/bodily-awareness/, 2011>. Acesso em: 02 ago. 2015, 2011 a.

. "Embodiment, Ownership and Disownership". In: Consciousness and Cognition, v.20, n.1, p.82-93, 2011b.

. "A Mosquito bite against the Enactive View to Bodily Experiences". In: Journal of Philosophy, v.108, n.4, p.188-204, 2011c.

"Bodily Immunity to Error". In: Prosser, Simon; Recanati, François. Immunity to Error Through Misidentification: New Essays. Cambridge: Cambridge University Press, 2012, p.224-246.

VINTIADIS, Elly. "Why a Naturalist Should Be an Emergentist about the Mind". In: SATS: Northern European Journal of Philosophy, v.14, n.1, p.3862, 2013. 